\title{
OPTIMALISASI VIDEO EDUKASI: UPAYA MENINGKATKAN KESADARAN MASYARAKAT DALAM MEMATUHI PROTOKOL KESEHATAN DI ERA NEW NORMAL
}

\author{
Komarudin $^{1}$, Laila Puspita ${ }^{2}$ \\ 1, 2 Universitas Islam Negeri Raden Intan Lampung, Indonesia \\ *e-mail: ${ }^{1}$ komarudin@radenintan.ac.id, 2 lailapuspita@radenintan.ac.id
}

\begin{abstract}
Abstrak: Awal tahun 2020, muncul wabah Corona Virus Disease 2019 (Covid-19). Minimnya kesadaran masyarakat untuk mematuhi protokol kesehatan menjadi salah satu pemicu meningkatnya penyebaran Covid-19 di indonesia. Kurangnya kesadaran masyarakat terhadap pentingnya mematuhi protokol Kesehatan, seperti tidak mengenakan masker, tidak jaga jarak, dan kesadaran untuk mencuci tangan menjadi salah satu penyebab penyebaran covid-19. Tujuan pengabdian ini adalah untuk meningkatkan kesadaran orang tua dan anak-anak untuk mematuhi protokol kesehatan di tengah wabah covid-19 melalui video edukasi. Metode yang digunakan dalam pengabdian ini yaitu sosialisasi berbatuan video edukasi. Instrumen yang digunakan dalam pengabdian ini yaitu angket kesadaran masyarakat terhadap bahaya covid-19. Hasil pengabdian menyatakan bahwa kesadaran masyarakat dalam mematuhi protokol kesehatan di era new normal mengalami peningkatan.
\end{abstract}

Kata kunci: Kesadaran Orang Tua; Covid-19; Corona Virus Disease; Kenormalan Baru; Protokol Kesehatan.

\begin{abstract}
Early in 2020, there was an outbreak of Corona Virus Disease 2019 (Covid-19). The lack of public awareness to comply with health protocols is one of the triggers for the increasing spread of Covid19 in Indonesia. Lack of public awareness of the importance of complying with health protocols, such as not wearing masks, not keeping a distance, and awareness to wash hands is one of the causes of the spread of covid-19. The purpose of this devotion is to raise awareness of parents and children to adhere to health protocols in the midst of the covid-19 outbreak through educational videos. The method used in this devotion is the socialization of rocky educational videos. The instrument used in this service is the public awareness of the dangers of covid-19. The results of the service stated that public awareness in complying with health protocols in the new normal era has increased.
\end{abstract}

Keywords: Parental Awareness; Covid-19; Corona Virus Disease; New Normality; Health Protocol.

\section{PENDAHULUAN}

Di era new normal ini, mengharuskan kita untuk terbiasa dengan tatanan hidup yang baru dengan kenormalan baru pula

@ Komarudin, Laila Puspita
(Mahardhani \& KP, 2020; Nicolas, 2021). Awal tahun 2020 ini, kita kagetkan dengan adanya penyebaran Corona Virus Disease 2019 (Covid-19). Covid-19 dapat 
menular dari manusia ke manusia (Al Hakim, 2021; Jaji, 2020), melalui kontak erat dan droplet (percikan cairan pada saat bersin dan batuk) tidak melalui udara. Ini merupakan fenomena yang sangat luar biasa yang terjadi di bumi pada abad 21. Minimnya kesadaran masyarakat untuk selalu mematuhi protokol kesehatan menjadi salah satu pemicu meningkatnya angka penyebaran Covid-19 di Indonesia (Ilpaj \& Nurwati, 2020; Puspita \& Komarudin, 2021). Adanya Covid-19 ini berdampak buruk pada perekonomian, pendidikan, dan lain sebagainya (Kusumadewi et al., 2020; Simatupang et al., 2020).

Untuk meninkatkan perekonomian dan pengembalian kehidupan masyarakat , pemerintah melalui kebijakan Pembatasan Sosial Bersekala Besar (PSPB) menjadi awal dilakukanya era new normal. Di era new normal ini, ada beberapa protokol kesehatan yang harus dipatuhi (Tukan, 2020), seperti kita diharuskan memakai masker, rajin mencuci tangan dengan sabun (handsanitizer), menjaga jarak aman minimal 1 meter, dan lain sebagainya (Brahmana, 2020; Fitria, 2020; Susilaksmi et al., 2020).

Tidak hanya di Kota, ternyata dampak dari wabah covid-19 sudah sampai ke pelosok desa (Mukhsar et al., n.d.; Nafilah, 2020; Suasthi \& Suadnyana, 2020; Zulkarnain et al., 2020), seperti yang dirasakan masyarakat Desa Bagelen kecamatan Gedong Tataan, Kabupaten Pesawaran, Provinsi Lampung, khususnya bidang perekonomian para petani karena memang sebagian besar masyarakat di Desa Bagelen berprofesi sebagai petani. Tidak hanya orang tua, di Desa Bagelen juga banyak anak anak yang masih melakukan aktivitas di luar rumah tanpa mematuhi protokol kesehatan yang diberlakukan pemerintah selama wabah

@ Komarudin, Laila Puspita covid-19. Kurangnya kesadaran orang tua dalam menaati peraturan yang ada juga berdampak pada anak mereka yang cenderung mengabaikan protokol kesehatan yang ada.

Berdasarkan latar belakang masalah diatas, maka perlu untuk dilakukan upaya peningkatan kesadaran orang tua dan anak-anak dalam mematuhi protokol kesehatan di era new Normal wabah covid19 melalui video edukasi. Video edukasi digunakan untuk menarik perhatian dan mempermudah orang tua dan anak-anak dalam memahami wabah covid-19.

\section{METODE}

Penulis melaksanakan pengabdian dengan cara membagikan edukasi yang dibuat semenarik mungkin dalam bentuk video yang diunggah ke dalam media sosila, lalu mengadakan sosialisasi dengan warga Desa Bagelen kecamatan Gedong Tataan, Kabupaten Pesawaran, Provinsi Lampung, sebanyak 40 peserta untuk meningkatkan kesadaran akan pentingnya mengajarkan dan membiasakan anak untuk tetap mematuhi protokol kesehatan ketika diluar rumah. Pengabdian ini dilakukan dengan mengadakan sosialisasi disertai pembuatan video edukasi anak tentang covid-19 dan bagaimana protokol Kesehatan yang harus dilakukan. Instrumen yang digunakan dalam penelitian ini yaitu angket kesadaran masyarakat terhadap bahaya covid-19.

\section{HASIL DAN PEMBAHASAN}

Program pengabdian ini dilakukan dengan menerapkan protokol kesehatan, yaitu work from home and social distancing. Adapun program yang dilakukan yaitu meningkatkan kesadaran orang tua untuk mendisiplinkan anak usia dini agar

$19 \mid \mathrm{K}$ a ibon Abhin a y 
mematuhi protokol kesehatan saat beraktivitas diluar rumah. Pengabdian dilaksanakan mulai tanggal 6 Juli- 15
Agustus 2020. Desain kegiatan program Pengabdian dapat dilihat pada Gambar 1 sebagai berikut.

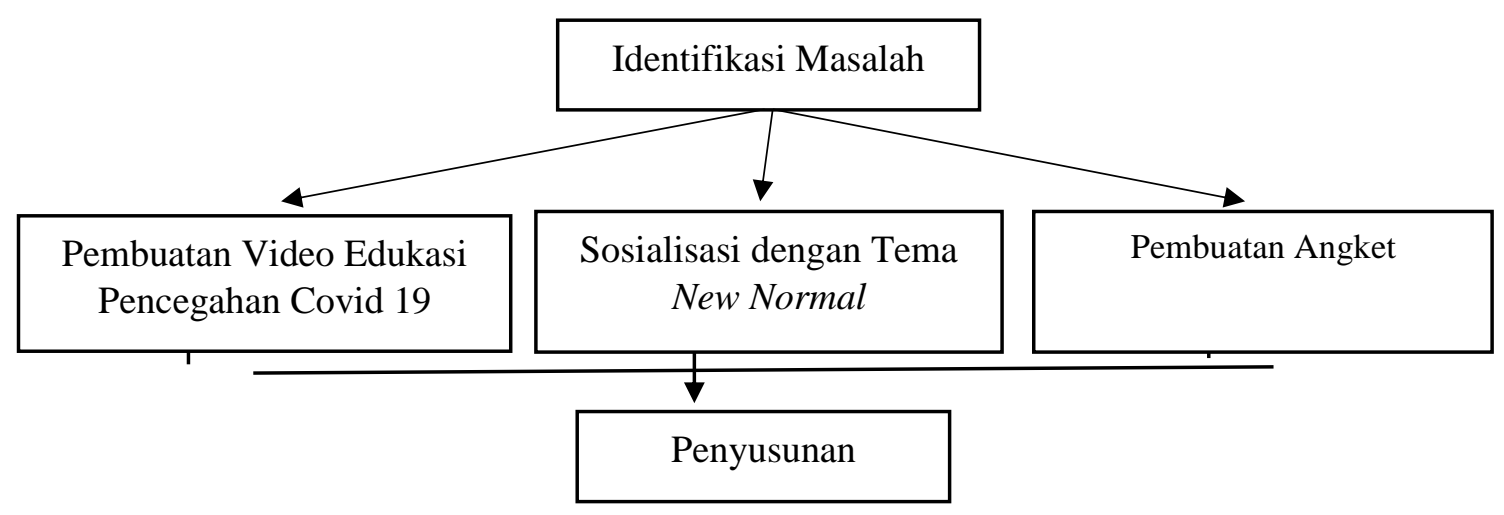

Gambar 1. Desain kegiatan program Pengabdian

a. Identifikasi masalah

Berdasarkan latar belakang masalah yang ada, maka dapat di jelaskan berdasarkan klasifikasi yang terdapat pada Tabel 1 sebagai berikut.

Tabel 1. Identifikasi Masalah dan Upaya Pencegahan

\begin{tabular}{clll}
\hline No & \multicolumn{1}{c}{ Masalah } & Alternatif Pemecahan & \multicolumn{1}{c}{ Bentuk kegiatan } \\
\hline 1. & $\begin{array}{l}\text { Kurangnya } \\
\text { pemahaman orang } \\
\text { tua terhadap Covid- } \\
19\end{array}$ & $\begin{array}{l}\text { Memberikan edukasi } \\
\text { tentang Covid-19 dan } \\
\text { petunjuk praktis } \\
\text { pencegahannya }\end{array}$ & $\begin{array}{l}\text { Membagikan edukasi } \\
\text { yang dibuat semenarik } \\
\text { mungkin dalam bentuk } \\
\text { video yang diunggah ke } \\
\text { dalam med sosial. }\end{array}$ \\
\hline 2. & $\begin{array}{l}\text { Kurangnya } \\
\text { kesadaran orang tua } \\
\text { akan pentingnya } \\
\text { mendisiplinkan } \\
\text { anak untuk selalu } \\
\text { menaati protokol } \\
\text { kesehatan }\end{array}$ & $\begin{array}{l}\text { Peningkatan kesadaran } \\
\text { orang tua akan } \\
\text { pentingnya melatih } \\
\text { anak untuk selalu } \\
\text { mematuhi protokol } \\
\text { kesehatan }\end{array}$ & $\begin{array}{l}\text { Mengadakan sosialisasi } \\
\text { dengan warga desa dan } \\
\text { memberikan angket }\end{array}$ \\
\hline
\end{tabular}

b. Edukasi

Edukasi ini berfokus pada masyarakat Desa Bagelen RT/ 002 RW/001 Kecamatan Gedong Tataan, Kabupaten Pesawaran. Edukasi dilakukan agar para audien (baca: mayarakat) lebih mudah memahami dan mengetahui tata cara penanggulangan Covid-19 (Hadi, 2017; Hidayati et al., 2019). Di dalam video terdapat beberapa pendapat anak usia dini mengenai tanggapan mereka tentang Covid-19 dan beberapa petunjuk praktis pencegahan untuk orang tua agar anak terhindar dari penularan Covid-19. 


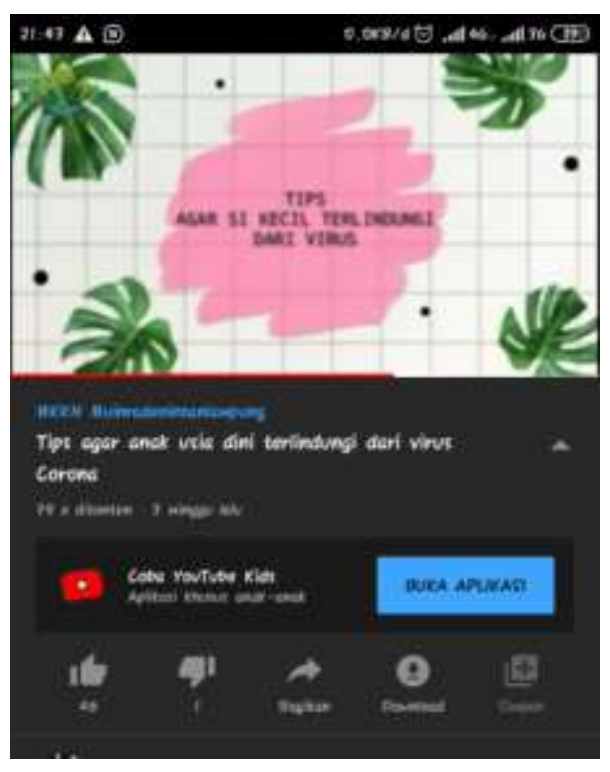

Gambar 2. Video Edukasi

\section{c. Sosialisasi}

Anak- anak perlu dilatih untuk membiasakan diri untuk selalu hidup bersih dan sehat, serta kebiasaankenormalan baru seperti memakai masker, dan selalu mencuci tangan dengan sabun sehingga terlindungi dari penularan berbagai macam penyakuit dan virus, termasuk Covid-19. Anakanak perlu dilatih untuk memakai masker dengan benar, yaitu dengan cara bertahap, pertama 30 menit, hari selanjutnya ditambah 10 menit, begitu selanjutnya. Sehingga ketika hendak bepergian, mereka sudah terbiasa memakai masker dengan jangka waktu yang lama. Anak juga diajak untuk selalu cuci tangan menggunakan sabun, dan diajarkan bagaimana mencuci tangan dengan baik dan benar.

Oleh sebab itu, orang tua harus paham bagaimana cara pencegahan Covid-19 dan apa saja yang harus kita lakukan di era new normal ini.
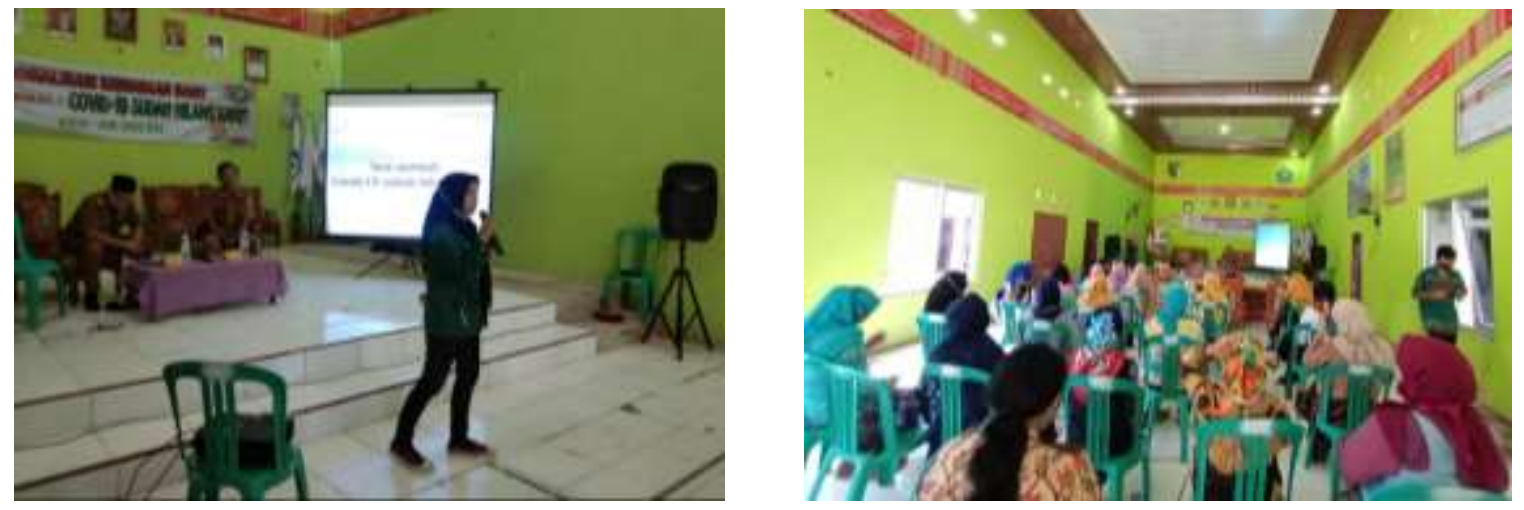

Gambar 3. Proses Sosialisasi Covid-19.

\section{d. Pembagian angket}

Angket yang dibuat dibagikan kepada perwakilan peserta dan masingmasing perwakilan diminta untuk mengisi sesuai pemahaman yang dimiliki oleh masing-masing mereka. Adapun hasil dari angket disajikan sebagai berikut. 


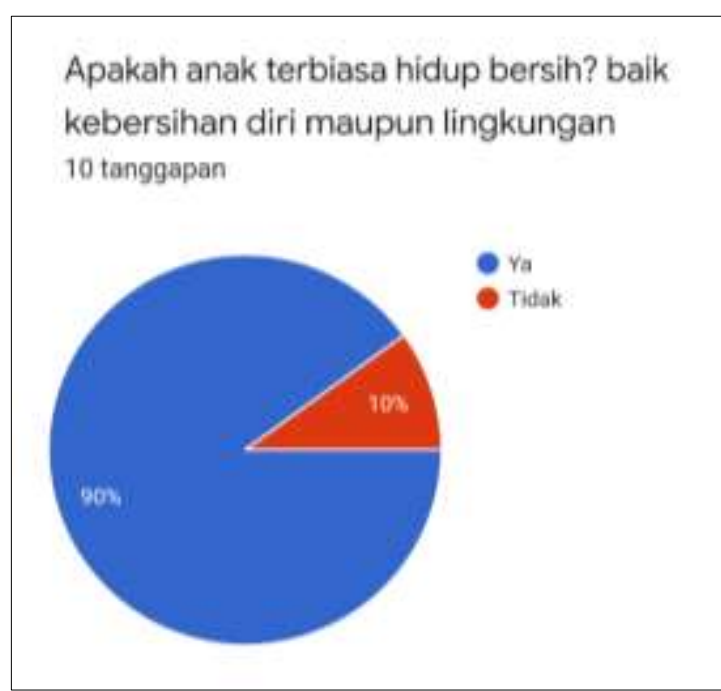

Apakah ayah/ bunda menjelaskan juga bagaimana cara pencegahannya?

10 tanggapan

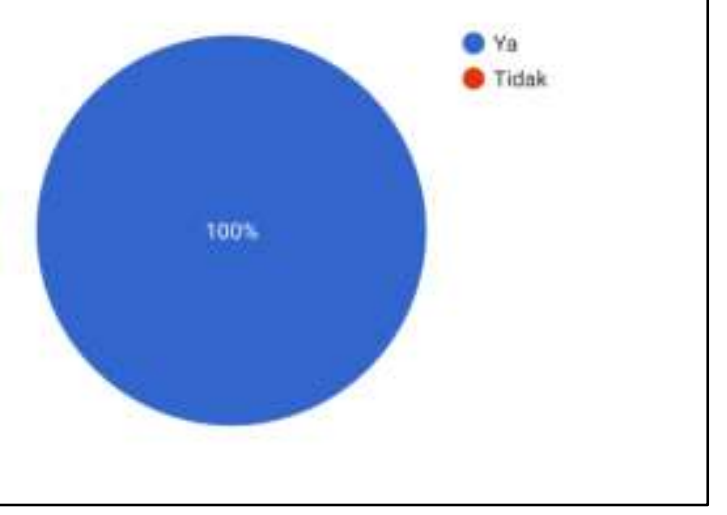

Setelah dipakaikan masker, apakah anak diberitahu mengapa kita harus memakainya? 10 tanggapan

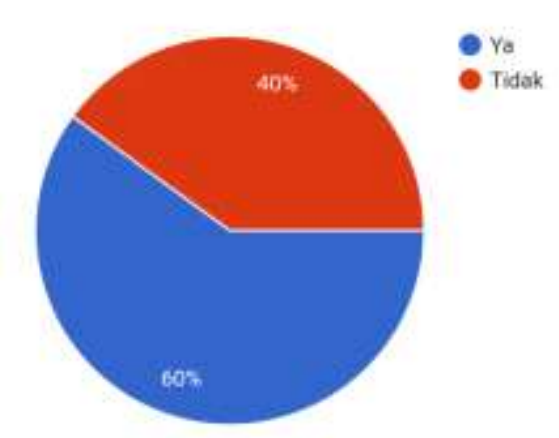

Ketika anak bertanya tentang wabah virus Corona, bagaim...elaskan kepada anak? 10 tanggapan

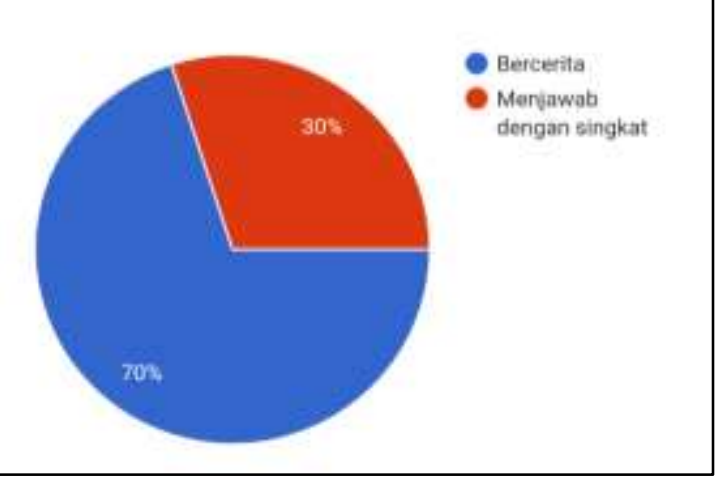

Apakah ayah/ bunda memberikan edukasi kepada anak ... wabah virus Corona? 10 tanggapan

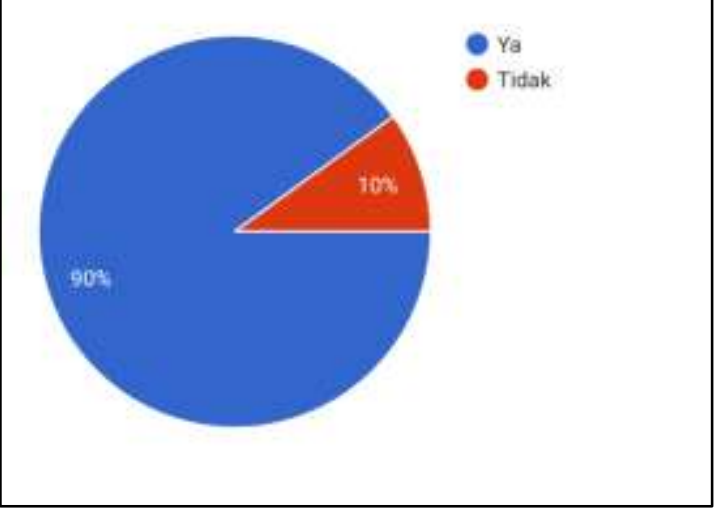

Ketika hendak keluar rumah, apakah anak dipakaikan masker?

10 tanggapan

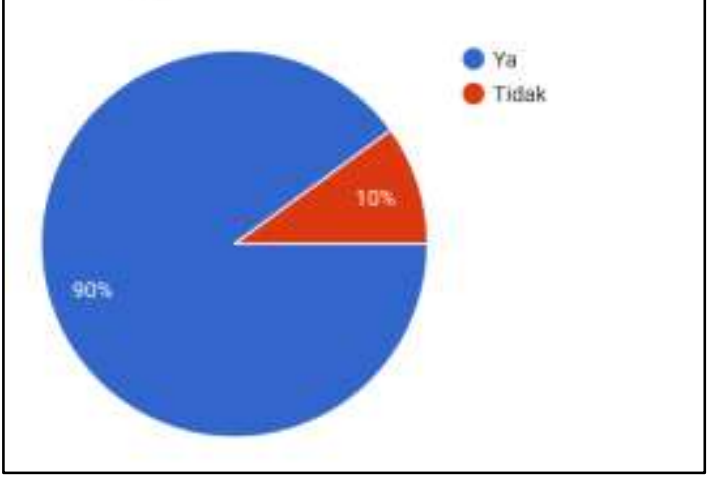



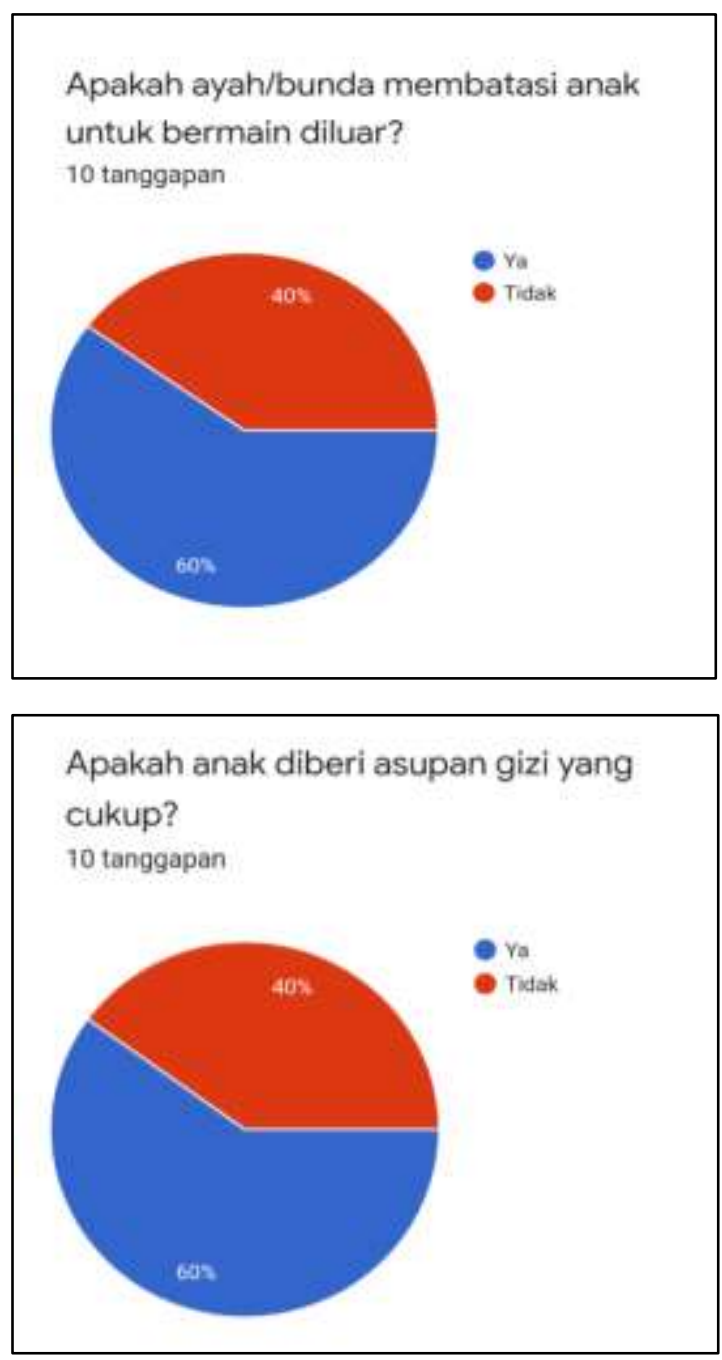

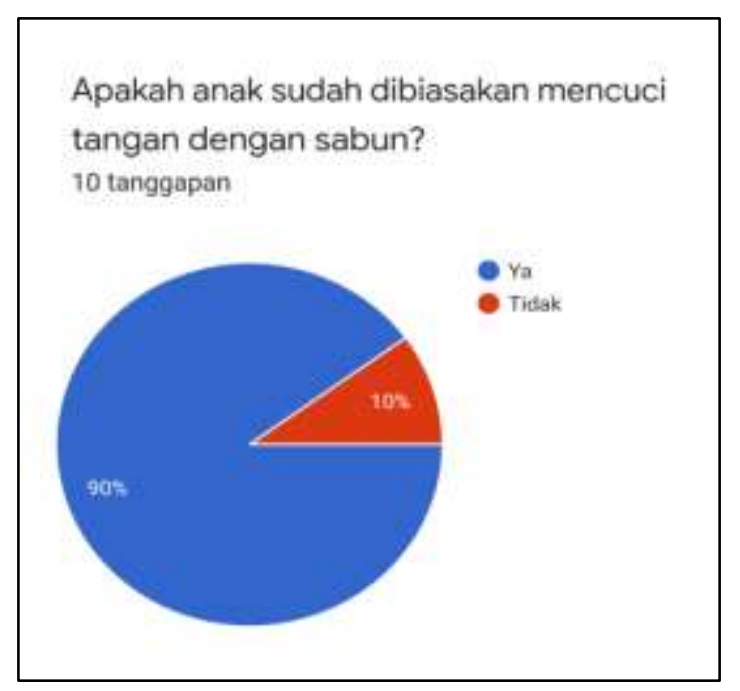

Apakah ayah/bunda sudah mengajarkan bagaimana cara menc... benar kepada anak? 10 tanggapan

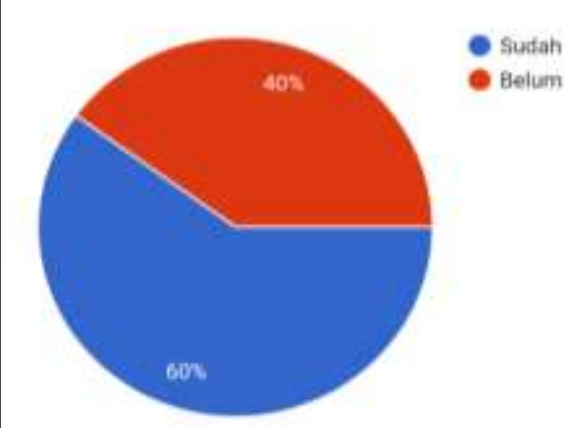

Gambar 4. Hasil dari Angket Kesadaran Masyarakat Dalam Mematuhi Protokol Kesehatan Di Era New Normal

Berdasarkan hasil angket di atas, diketahui bahwa hampir $80 \%$ peserta yang diberi angket telah memahami bagaimana cara dan kriteria hidup sehat, khususnya yang berkaitan dengan dengan protokol Kesehatan ditengah wabah Covid-19, seperti keharusan memakai masker, rajin mencuci tangan dengan sabun (handsanitizer), menjaga jarak aman minimal 1 meter, dan lain sebagainya.

\section{KESIMPULAN}

Kegiatan pengabdian di lingkungan Desa Bagelen Kecamatan Gedong Tataan Kabupaten Pesawaran telah berhasil dilakukan. Berdasarkan hasil dan pembahasan diketahui bahwa kesadaran masyarakat dalam mematuhi protokol kesehatan di era new normal mengalami peningkatan

\section{UCAPAN TERIMA KASIH}

Pendamping menyampaikan ucapan terimakasih kepada pihak terkait dalam mendukung suksesnya pelaksanaan pengabdian masyarakat ini. Utamanya kepada Lembaga Penelitian dan Pengabdian Masyarakat . UIN Raden Intan Lampung. Selain itu, Rektor UIN Raden Intan Lampung yang terus mendukung upaya meminimalisir dampak akibat adanya wabah covid-19 ini 
melalui berbagai program kegiatan. Kemudian, para aparat desa dan warga Desa Bagelen RT/RW: 002/001 Kecamatan Gedong Tataan, Kabupaten Pesawaran atas Kerjasama dan yang berkontribusi langsung dan tidak langsung dalam mendukung suksesnya kegiatan dimaksud. Semoga, upaya kita dapat menjadi berkah demi keselamatan dan kemajuan masyarakat .

\section{REFERENSI}

Al Hakim, R. R. (2021). Pencegahan penularan Covid-19 berbasis aplikasi Android sebagai implementasi kegiatan KKN tematik Covid-19 di Sokanegara Purwokerto Banyumas. Community Engagement and Emergence Journal (CEEJ), 2(1), 7-13.

Brahmana, I. B. (2020). Edukasi Pencegahan Penularan Covid-19 Bagi Tenaga Kesehatan Dan Pasien Di Poliklinik Rawat Jalan Obsgin. Jurnal Edukasi Masyarakat, Pengabdian Dan Bakti, 1(1), 21-35.

Fitria, N. J. L. (2020). Penerapan Work From Home Dan Work From Office Dengan Absensi Online Sebagai Implikasi EGovernment Di Masa New Normal. Civil Service Journal, 14(1 Juni), 69-83.

Hadi, S. (2017). Efektivitas penggunaan video sebagai media pembelajaran untuk siswa sekolah dasar. Seminar Nasional Teknologi Pembelajaran Dan Pendidikan Dasar 2017, 96-102.

Hidayati, A. S., Adi, E. P., \& Praherdhiono, H. (2019). Pengembangan media video pembelajaran untuk meningkatkan pemahaman materi gaya kelas IV di SDN Sukoiber 1 Jombang. JINOTEP (Jurnal Inovasi Dan Teknologi Pembelajaran): Kajian Dan Riset Dalam Teknologi Pembelajaran, 6(1), 45-50.
Ilpaj, S. M., \& Nurwati, N. (2020). Analisis Pengaruh Tingkat Kematian Akibat Covid-19 Terhadap Kesehatan Mental Masyarakat di Indonesia. Focus: Jurnal Pekerjaan Sosial, 3(1), 16-28.

Jaji, J. (2020). Pengaruh Pendidikan Kesehatan Dengan Media Leafletterhadap Pengetahuan Warga Dalam Pencegahan Penularan Covid-19. Proceeding Seminar Nasional Keperawatan, 6(1), 135-140.

Kusumadewi, R. F., Yustiana, S., \& Nasihah, K. (2020). Menumbuhkan Kemandirian Siswa Selama Pembelajaran Daring Sebagai Dampak Covid-19 Di Sd. Jurnal Riset Pendidikan Dasar (JRPD), 1(1).

Mahardhani, A. J., \& KP, M. (2020). Menjadi Warga Negara yang Baik pada Masa Pandemi Covid-19: Persprektif Kenormalan Baru. JPK (Jurnal Pancasila Dan Kewarganegaraan), 5(2), 65-76.

Mukhsar, M., Usman, I., Abapihi, B., Sani, A., \& Baharuddin, B. (n.d.). Penguatan Desa Siaga COVID-19. Jurnal Pengabdian Masyarakat Ilmu Terapan (JPMIT), 2(2), 133-138.

Nafilah, Z. A. (2020). Langkah Taktis Pencegahan Covid-19 di Desa Lowayu Kecamatan Dukun Kabupaten Gresik. Prosiding Penelitian Dan Pengabdian Kepada Masyarakat , 7(2), 360-370.

Nicolas, D. G. (2021). Diskursus Problem dan Solusi dalam Penanganan Administrasi Pendidikan Kristen Di Kehidupan New Normal. Jurnal Syntax Transformation, 2(1), 41-53.

Puspita, L., \& Komarudin, K. (2021). Peningkatan Ekonomi Masyarakat : Dampak Pemanfaatan Ampas Susu Kedelai Menjadi Nugget. Dinamisia: Jurnal Pengabdian Kepada Masyarakat, 5(1). 
Simatupang, N. I., Sitohang, S. R. I., Situmorang, A. P., \& Simatupang, I. M. (2020). Efektivitas pelaksanaan pengajaran online pada masa pandemi covid-19 dengan metode survey sederhana. Jurnal Dinamika Pendidikan, 13(2), 197-203.

Suasthi, I. G. A., \& Suadnyana, I. B. P. E. (2020). Membangun Karakter "Genius" Anak Tetap Belajar Dari Rumah Selama Pandemi Covid-19 Pada Sekolah Suta Dharma Ubud Gianyar. Cetta: Jurnal Ilmu Pendidikan, 3(3), 431-452.

Susilaksmi, I., Triharyanto, Y. A., Yahya, M. Z., Sadewa, M. M., \& Hidayat, S. S. (2020). Menghadapi Era Adaptasi Kebiasaan Baru Dari Pandemi Covid19 Pada Bidang Kesehatan Di Kabupaten Batang. RISTEK: Jurnal Riset, Inovasi Dan Teknologi Kabupaten Batang, 5(1), 8-13.

Tukan, R. A. (2020). Mengulik Perilaku 'bandel'masyarakat Di Tengah Pandemik Covid-19. Antologi Dari Bumi Paguntaka: Covid-19: Dampak Dan Solusi, 12.

Zulkarnain, F., Nurdin, A. A., Gojali, N., \& Wahyu, F. P. (2020). Kebijakan fatwa MUI meliburkan shalat jumat pada masa pandemi Covid-19. Kebijakan Fatwa MUI Meliburkan Shalat Jumat Pada Masa Pandemi Covid-19. 